\title{
Tek Parti Döneminde Hükümet Memur Dayanışması
}

\author{
Fatih TUĞLUOĞLU*
}

\section{ÖZET}

Bu makalede, İkinci Dünya Savaşı sırasında Türkiye'de yaşanan ekonomik sıkıntılar nedeniyle devlet memurlarına yapılan aynî ve nakdî yardımlar Başbakanlık Cumhuriyet Arşivindeki belgelere dayanılarak ele alınmıştır. Savaşın etkilerinin ülkemizde hissedilmeye başlandığı 1940 yılında ülkeyi savaşa hazır duruma getirmek için Milli Korunma Kanunu çıkarılmıştır. Bu kanun çerçevesinde ülkede sıkıntısı çekilen gıda maddelerinin daha düzenli bir şekilde dağıtımına geçilmiş ve ihtiyaç maddelerinin tüketimi sınırlandırılmıştır. Bu süreçte yüksek enflasyonun neden olduğu hayat pahalılığıyla mücadele etmek zorunda kalan devlet memurları, hükümetin, kendilerine halktan farklı olarak yaptığı aynî ve nakdî yardımlardan faydalanmışlardır. Bu yardımlar memurların kıdemlerine, çeşitlerine ve ailelerinin durumuna göre farklılık göstermekteydi. Memurlar, elbise, yakacak ve gıda maddelerini halktan daha ucuz fiyatla temin edebilmişlerdir. İhtiyaç maddelerinin memurlara halktan farklı bir biçimde ulaştırılmaları, memur-halk ikilemine yol açmıştır. Bu ikilem çok partili hayata geçiş sürecinde halkın Cumhuriyet Halk Partisinden uzaklaşmasma neden olmuștur.

Anahtar kelimeler: Memur, Karne uygulaması, Milli Korunma Kanunu, Ekmek, Giyim yardımı, Gıda yardımı, Yakacak yardımı, Nakdi yardımlar, Cumhuriyet Halk Partisi.

\section{The Government-Civil Servants Solidarity during The Single Party Period}

ABSTRACT

In this article, during the Second World War, the aids in kind and cash given to civil servants by the government is investigated based on republic archives documents. In 1940, when the effects of the war began to feel, National Protect Law was passed in order to prepare for war to country. In the frame of this law, food

\footnotetext{
• Ankara Üniversitesi Türk İnkılap Tarihi Enstitüsü, Doktora Öğrencisi.
} 
necessities that were in short in the country were delivered orderly to people and the consumption of food was restricted. In this period, state had to struggle with high inflation because of stagnation in economy. Civil servants took aids in kind and cash as different from people. This aid was given to State officials according to their ranks, number of members of family and other things. State officials took clothes, food and fuel cheaper than people. Therefore, this situation caused to the paradox between people and state officials. This paradox also caused people to alienate from Republic People's Party in the progress of entering multi-party stage.

Key Words: Civil servant, Practice of quota in distributing food, Bread, National Protect Law, Aid of Clothing, Aid of Food, Aid of Fuel, Aid of Money, Republic People's Party.

\section{GİRIŞ}

1 Eylül 1939 tarihinde Almanya'nın, Polonya'ya saldırmasıyla başlayan İkinci Dünya Savaşı, kısa sürede oldukça geniş cephelere yayılmış ve Türkiye'yi de tehdit etmekte gecikmemiştir. Genişleyen ve artan tehlike karşısında Türkiye, bir taraftan tarafsızlığını korumaya çalışırken diğer taraftan da her an savaşa girecekmiş gibi ordusunu seferber hale sokmuş ve yedeklerle bir milyon asker silah altına alınmıştır. Ülke ekonomisinin dayandığ 1 iş alanlarından, binlerce insanın çekilerek silah altına alınması, makine ve gübre gibi gereksinimleri ülkeye yeterince ithal edilememesi tarımsal üretimin düşmesine neden olmuştur'. Ayrıca artan asker sayısı ve savaş durumu savunma harcamalarının giderek artmasına yol açmış ve bu durum çok güçlü olmayan Türk ekonomisine büyük bir darbe vurmuştur.

Savaşın Akdeniz ve çevresine kayması nedeniyle, ithalat ve ihracat imkanları önemli ölçüde azalan Türkiye'de mal ve yedek parça sıkıntısı çekilmeye başlanmıştır. Bütçe gelirleri ise bu dönemde hem normal vergileri artırmak hem de olağanüstü vergiler koymak suretiyle artırılmak istenmiştir. Dolaylı ve dolaysız vergilerin (muamele ve kazanç) oranları yükseltilmiş, tekel maddelerinin fiyatlarına da zam yapılmıştır. Sürekli fiyat artışları sonucu 1938'de 100, 1939'da 101 olan fiyat artışları sonucu fiyat endeksi 459'a çıkmıștır². 1939 yılında toplam ihracatımız 127 milyon, ithalatımız 118 milyon TL iken, 1940 yılı ihracatımız 111,5 milyon, ithalatımız 69

${ }^{\prime} 1939$ yılında 100 olan tarım üretim endeksi, 1940'de 90,5, 1941'de 98, 1942'de 86. 1943'de 81,9, 1944'de 70,4 olarak gerçekleşmiştir. Ayrıntılı bilgi için bkz: Stefanos Yerasimos, Azgelişmişlik Sürecinde Türkiye, (Çeviren Babür Kuzucu), C.3, İstanbul 1992, s.150.

${ }^{2}$ Taner Timur, Türk Devrimi ve Sonrası, Ankara 1997, s.209. Bu dönemde Türkiye'de tedavüldeki kağıt para miktarı 1938'de 100 iken, 1939'da 153,1940 'da 216,1941 'da 269. 1942 'de 384,1943 'de 415,1944 'de 498,1945 'de 455,1946 'da 480 'dir. Yerasimos, a.g.e., s.149. 
milyon TL olarak gerçekleşmiş ve Cumhuriyet döneminin en düşük değerine inmiştir ${ }^{3}$.

Bu şartlar içinde bulunan Türkiye'de, ilk aşamada hükümet, mevcut imkanlarla ordunun ve halkın ihtiyacını karşılayabilmek için farklı çözüm arayışlarına girişmiştir.

\section{Stkıntılara Çöziim Arayıșı ve Milli Korunma Kanunu}

Hükümet, silah altına aldığı askerlerini beslemek ve şehir merkezlerinin gıda ve giyim gibi temel mal gereksinimlerini karşılamakta oldukça güçlük çekmekteydi. Ayrıca hızla artan karaborsacılık ve vurgunculuk, hükümetin sıkıntılarını daha da artırıyordu. Zorunlu ihtiyaç maddelerinin çok zor temin edilebilmesi, geniş halk kitlelerini sefalete iterken, bu durum hükümeti sıkıntılara çözüm arama yoluna itmiştir ${ }^{4}$. Hükümet, ilk aşamada askeri ihtiyaçları göz önüne alarak 18 Ocak 1940 tarihinde ordunun ihtiyaçlarını karşılayabilmek ve üretimi artırmak için Milli Korunma Kanunu çıkarmıştır ${ }^{5}$.

Türk ekonomisini, savaş şartlarına hazırlamak amacıyla çıkarılan bu kanunla, hükümet, iktisadi hayata çok geniş bir müdahale imkanı elde etmekteydi. Hükümetin müdahale hakkı, üretimle ilgili konularda toplanmış olup sınai ve tarımsal üretimi savaş döneminin ihtiyaçlarına uygun hale getirmeyi hedeflemiştir ${ }^{6}$. Hükümet bu amaçla sanayii ve madenlerde üretimi ülkenin ihtiyacı oranında artırmak amacıyla bu kurumlara işçi ve uzman eleman temin etme yoluna gitmiştir. Bu nedenle hükümet sanayii kuruluşlarının ve madenlerin bulunduğu bölgelerde yaşayan vatandaşlara ücretli iş yükümlülüğü getirmiştir? .

Milli Korunma Kanunu'nun, toplumda en çok hissedilen etkisi fiyat kontrolleridir. Hükümet, 14 Şubat 1940 tarihinde Ticaret Bakanlığına bağlı olarak Ticaret Ofisini kurarak, piyasada az bulunması nedeniyle karaborsaya düşen ihtiyaç maddelerinin fiyatlarını belirleme yetkisini bu kuruma vermiştir ${ }^{8}$.

Ticaret Ofisi'nin amacı, fiyatları kontrol altında tutarak karaborsayı önlemekti. Bu amaçla Toprak Mahsulleri Ofisi de kurularak hububat üzerinde fiyat kontrolünün sağlanması hedeflenmekteydi. Hububatın gittikçe azalması karşısında Hükümet, Milli Korunma Kanuna dayanarak zorlayıcı tedbirler uygulama yoluna gitmiştir. Buğdayın gittikçe azalması şehirlerde

\footnotetext{
${ }^{3}$ Timur, a.g.e., s.175.

4 Yahya Sezai Tezel, Cumhuriyet Döneminin Iktisadi Tarihi, Ankara 1986, s.223; Mahmut Goloğlu, Milli Şef Dönemi, Ankara 1972, s.163.

${ }^{5}$ Milli Korunma Kanunu, Kanun No: 3780, Düstur, 3. Tertip, C.21, Ankara 1940, s.433.

${ }^{6}$ Timur, a.g.e., s.177.

${ }^{7}$ Timur, a.g.e., s.178.

${ }^{8}$ Ayruntılı bilgi için bkz: Dïstur, 3. Tertip, C.22, Ankara 1941, s.274
} 
ekmeğin fiyatının artmasına ve hayat pahalılığına neden olmaktaydı. Bunun üzerine hükümet hububat ürününü, serbest piyasa fiyatının altında almaya başlamıştır. Ancak alınan bu önlemler iaşe sonuna çare olamayınca Hükümet Milli Koruma Kanunun 14. maddesine $e^{9}$ dayanarak 1942 yılından itibaren tüm hububat ürünlerinden ekmeklik, yemeklik, tohumluk ve yemeklik ihtiyaçları dışındaki çavdar, mahlut, mısır, darı, yulaf, arpa ve buğdaya Hükümet el koymuştur ${ }^{10}$. Hükümetin, ekmek fiyatlarının yükselmesinden dolayı geçim sıkıntısı çeken şehirlileri rahatlatmayı amaçlayan bu girişimi köylülerin tepkisini çekmekteydi ${ }^{11}$. Çünkü ofis, buğdayı köylülerden piyasa fiyatının altında satın almaktaydı ${ }^{12}$.

Alınan tüm önlemlere rağmen ihtiyaç maddeleri piyasada bulunamıyor, ancak yüksek kâr peşinde koşan esnaf ve tüccarlar tarafından piyasada temin edilemeyen her türlü mal normalin çok üstünde bir fiyatla karaborsada satılabiliyordu. Yakup Kadri Karaosmanoğlu, o dönemde karaborsacılığın yaygınlığını şöyle anlatmaktadır: “...zeytinyağı piyasasını inhisarı altına alan bakan mı istersiniz; karaborsacıları koruyan vali, umum müdür vesaire mi istersiniz, o devirde bunların her köşe başında size sırıttıklarının görebilirdiniz"13.

Metin Toker ise karaborsayla gerçek anlamda mücadele edilemediğini belirterek; "Karaborsa ile mücadele hoş, fakat boş bir laftan başka bir şey değildi. Karaborsa ile mücadele için görevli olanlar büyük rüşvetle susturuluyorlar...." șeklinde o dönemde yașananları ifade etmektedir ${ }^{14}$.

Sabit ve dar gelirli vatandaşlar ülkenin bu durumu karşısında oldukça büyük zarar görmekteydiler. Karaborsada bulunan temel ihtiyaç maddelerini temin edemeyen memur, emekli ve dar gelirliler hayat seviyelerini oldukça düşürmek zorunda kalmışlardır.

Bu süreçte tarımsal üretimin düşmesi, ülkede hububat sıkıntısını artırmış, yurtdışından ithalat imkanlarının da kısıtlı olması nedeniyle ülkenin çeşitli

\footnotetext{
${ }^{9}$ Mili Korunma Kanunun 14. maddesi; "Maddelerin veya yardımcı malzemelerin muayyen ellerinde toplanarak halk ve milli müdafaa ihtiyacının tazyıka düşürülmesine meydan vermemek için Hükümet, değer fiatı mukabilinde bunlara el koyarak ihtiyact olan müesseselere karsız tevzi edebilir" şcklindedir. Düstur, 3. Tertip, C.21, Ankara 1940, s.435.

${ }^{10}$ Şevket Pamuk, "İkinci Dünya Savaşı Yıllarında İaşe Sorunu ve Köylülük", Tarih ve Toplum, Sayı:35, Kasım 1986, s.283.

${ }^{1}$ Kemal Karpat, Türk Demokrasi Tarihi-Sosyal, Ekonomik, Kültürel Temeller, İstanbul 1996.s.102.

${ }^{12}$ Pamuk, a.g.m., s.283-284.

${ }^{13}$ Yakup Kadri Karaosmanoğlu, Politikada 45 Yıl, İletişim Yayınları, İstanbul 1999. s.158-159.

${ }^{14}$ Metin Toker, Tek Partiden Çok Partive 1944-1950, Bilgi Yayınevi, Ankara 1998, s.24. Aynı şekilde Şevket Süreyya Aydemir de karaborsayı önlemekle görevli zabıta memurlarının rüşvet aldıklarını örnekleriyle anlatmaktadır. Ayrıntılı Bilgi için bkz, Şevket Süreyya Aydemir, Ikinci Adam, C.2, 2000, s.216.
} 
yerlerinden bu sıkıntıları gösteren çok sayıda rapor merkeze gönderilmiştir. 15 Ekim 1942 tarihinde İktisat Vekili Sırrı Day tarafından Ticaret Vekaletine yazılan ve bir örneği de Başvekalete gönderilen raporda, Karabük DemirÇelik fabrikalarında baş gösteren iaşe sıkıntısından bahsedilmektedir. Sırrı Day, Safranbolu'ya bağlı Karabük Nahiyesinde 3500'e yakın iş̧̧i bulunmakta olduğunu ve bunlara günlük 45 çuval un verilmesi lazım gelirken ihtiyaçların ancak bir gün tam bir gün yarım olarak karşılanabildiğini belirtmektedir. Sırrı Day, Savaşın tam ortasında bulunduğumuz bu devirde "çok muhtaç olduğumuz demir ve kok üretiminin durmaması için Karabük fabrikalarının da Zonguldak ve Kırıkkale gibi askeri rejimle ekmek ihtiyaçlarının teminini" istemektedir ${ }^{15}$.

O dönemde İaşe Müsteşarı Muavini olarak iaşe işlerinden sorumlu olan Şevket Süreyya Aydemir, ülkenin günlük, halk için 1000 ton, 1000 ton da askeriye için de hububata ihtiyacı olmasına rağmen, günlük ancak 2 tonluk hububatın tedarik edilebildiğini ifade etmektedir ${ }^{16}$.

Tarımsal üretimdeki düşüş ve İkinci Dünya Savaşı'nın Akdenize de kayması nedeniyle başlayan ablukalar yüzünden ihtiyacı oranında ithalat yapamayan hükümet son çare olarak ülkedeki tüketimi kısma yoluna gitmiştir.

\section{Tek Tip Ekmek Uygulamast}

Tarımsal üretimin ülkedeki tüketim için yeterli olmaması nedeniyle, hükümet eldeki mevcut imkanları daha verimli kullanabilmek amacıyla, Milli Korunma Kanunun 21. maddesinde yer alan "halkın ve milli müdafaanın kat'i ihtiyacı olan zaruri maddelerin istihlak miktarını lüzum halinde hükümet tayin ve tespit eder" hüküm gereğince 18 Şubat 1941 tarih ve 2/15224 numaralı kararname ile tek tip ekmek çıkarılmasına karar verilmiştir. Bu karar uyarınca ülke genelindeki ekmeklere \%15 oranında çavdar katılması kararlaştırılmıştır ${ }^{17}$.

Tarımsal üretimin düşmesi, ekmeğin çeşnisinin sürekli değiştirilmesine, içindeki un miktarının sürekli azaltılmasına neden olmaktaydı. 6 Haziran 1941 tarihinde çıkarılan 2/15956 sayılı kararname ile ekmeğin çeşnisinin yeniden düzenlemesi yoluna gidilmiştir. Ayrıca bu kararname ile francala tipi ekmek imalatı sınırlandırılmış ve ekmeğe katılacak arpa ve çavdar miktarları artırılmıştır. Buna göre ekmek yapılırken una \%20 oranında arpa, $\% 30$ da çavdar katılması kararlaştırılmıştır. Ekmekte bu şekilde değişiklik yapılmasının yanı sıra çeşitli yerlerde farklı uygulamalara rastlanmaktaydı.

\footnotetext{
${ }^{15}$ Başbakanlık Devlet Arşivleri Genel Müdürlüğü, Cumhuriyet Arşivi, Başbakanlık Muamelat Genel Müdürlüğü Evrakı, Bundan sonra (BMGME) şeklinde kısaltılarak yazılacaktır, Katalog No: 030.10.185.274.6; Buna benzer bir örneği de Trabzon-Akçaabat'tan gönderilen, BMGME: Katalog No:030.10185.1, no’lu belgeden öğrenmekteyiz..

${ }^{16}$ Aydemir, a.g.e., s.203-204.

${ }^{17}$ Dïstur, 3. Tertip, C.21, Ankara 1940, s.436.
} 
Mesela İzmir'de palamut ve küspe de ekmeklik una karıştırılmış ve sonunda taşla moloz arası kara bir hamur parçası ekmek adı altında halka satılmıştır ${ }^{18}$.

Tek tip ekmek çıkartarak stoklardaki buğdayı daha verimli kullanmayı hedefleyen hükümet, piyasada her türlü ihtiyaç maddelerinde fiyat artışlarını engelleyemiyordu. Avrupa'da savaşın devam etmesi nedeniyle bütün yiyecek, içecek, yakacak ve ev eşyası fiyatlarında görülen artış özellikle yabancı kaynaklı ürünlerde devam ediyordu. Bu durumdan istifade eden bazı spekülatörlerin ve vurguncuların çeşitli malların fiyatlarını keyfi olarak yükselttikleri görülmekteydi ${ }^{19}$. Memurların sürekli artan fiyatlar karşısındaki sıkıntılı durumu bazı valilerin gözünden kaçmamış ve Başvekalete yazdıkları yazılarla bu husus için çözüm önerileri sunmuşlardır. 31 Ekim 1941 tarihinde Bursa Valisinin Başvekalete gönderdiği yazı bunun güzel örneklerinden biridir. Bursa Valisi Refik Koraltan memurların sıkıntı içerisinde bulunduğunu ve memurların "çocukların idare edemediklerini, tahsildeki çocuklarının tahsiline yetişemediklerini" belirtmektedir. Koraltan bu duruma çözüm olarak bazı önerilerde bulunmaktadır. Memurlara gıda maddelerini hazırlayıp vermenin ve ayrıca maaşlara yapılacak 15-20 liralık zammın faydalı olmayacağını, aksine sıkıntıları artıracağını belirtmektedir. Çözüm olarak yiyecek maddelerinin devletin memurlarına ucuz bir şekilde tedarik etmenin en mantıklı yol olacağını ifade etmektedir. Vali Refik Koraltan ayrıca 1939-1941 yıllarında Bursa piyasasındaki yiyecek, giyecek ve yakacak maddelerinin fiyatlarını ve artış yüzdelerini bir cetvel halinde hazırlamış ve Başbakanlığa sunmuştur ${ }^{20}$. Bu cetveldeki ihtiyaç maddelerinin fiyatları ile memur maaşlarımı ${ }^{21}$ karşılaştırarak o dönemdeki memurların alım gücü hakkında fikir sahibi olabiliriz.

\footnotetext{
${ }^{18}$ Aydemir, a.g.e., s.203

${ }^{19}$ Metin Ayışığı, "İkinci Dünya Savaşı Başlarında İstanbul'da İhtikar Meselesi”, Altınct Askeri Tarih Semineri Bildirileri 1, 20-22 Ekim 1997, İstanbul 1999, s.244-245. Fiyatların aşırı yükselmesini önlemek için hükümetin aldığı tedbirler için bkz. Ayışığı, a.g.m., s.236.

${ }^{20}$ BMGME:030.10.65.436.11.

${ }^{21} 30$ Haziran 1939 tarihinde çıkarılan Devlet memurlarının aylıklarına ilişkin kanunla memur maaşlanı belirlenmiştir. Bu kanunla, o dönemde Ankara'da Maliye Vekaletinde 6. derecede olarak çalışan bir müdür $70 \mathrm{TL}, 12$. derecede olan bir memur $25 \mathrm{TL}$, tașrada bulunan 1. sinif vali $150 \mathrm{TL}, 6$. derecede bulunan bir kaymakam $70 \mathrm{TL}, 13$. derecede bulunan bir nahiye müdürü $20 \mathrm{TL}, 15$. derecede bulunan bir nüfus memuru ise $20 \mathrm{TL}$ maaş almaktadır. Ayrıntılı bilgi için Bkz: "Devlet Memurlanı Aylıklarının Tevhid ve Teadülüne Dair Kanun", Kanun No:3656, Düstur 3. Tertip C.20. Ankara 1939, s.1444-1446; 25 Ocak 1944 tarihi itibariyle genel bütçe, katma, hususi bütçelerle belediyelerden maaş alanlarla emekli, dul ve yetimlerin sayısı toplam 316.576 kişidir. Aylık tutarı 10 liradan az olan ücretli ve maaşlı memur ve müstahdemlerin sayısı da 31.542 kişidir. Başbakanlık Devlet Arşivleri Genel Müdürlüğü, Cumhuriyet Arşivi, Başbakanlık Bakanlar Kurulu Kararları Evrakı. Bundan sonra (BBKKE) şeklinde kısaltılacaktır. Katalog No:030.10.15.87.32.
} 
Tablo 1. 1939-1941 yılları arasında ihtiyac maddelerinin fiyatları

\begin{tabular}{|c|c|c|c|}
\hline Yiyecek Maddeleri & 1939 & 1940 & 1941 \\
\hline & Kuruş & Kuruş & Kuruş \\
\hline Un & $700-650$ & $900-750$ & 1278 \\
\hline Ekmek & $9-10$ & 11 & 14.50 \\
\hline Buğday & $3.50-4,50$ & $6-7$ & $9-10,50$ \\
\hline Tereyağ & $90-110$ & $110-120$ & $175-180$ \\
\hline Pirinc & $25-27$ & $26-32$ & $40-50$ \\
\hline Zeytinyağ1 & $46-50$ & $47-50$ & $75-80$ \\
\hline Toz şeker & $36-26,50$ & $36-37$ & 48 \\
\hline Kesme & $30-31$ & $41-42$ & 52 \\
\hline Zeytin & 12 & $15-19$ & $35-38$ \\
\hline Peynir & $35-37,50$ & $40-45$ & $60-70$ \\
\hline Koyun eti & $35-40$ & 50 & 65 \\
\hline Siğır eti & $28-30$ & $33-35$ & $50-55$ \\
\hline Sabun & $19-20$ & 22 & 45 \\
\hline Makarna & 1.25 & $1,25-1,50$ & $2,25-2,50$ \\
\hline Yumurta & $2-3$ & $2,50-4$ & $4-6$ \\
\hline Soğan & $2-4$ & $4-6$ & $7-9$ \\
\hline Patates & 10 & $10-11$ & $14-16$ \\
\hline Süt & 10 & $14-16$ & $24-25$ \\
\hline Yoğurt & 10 & $10-16$ & $24-25$ \\
\hline Çay & 335 & 550 & 1000 \\
\hline Fasulye & 11 & 15 & $22-18$ \\
\hline Nohut & 7 & 9 & $20-15$ \\
\hline Mercimek & 8,50 & 10 & 22 \\
\hline
\end{tabular}




\begin{tabular}{|l|c|c|c|}
\hline Odun & $0,70-1,25$ & $1,25-1.50$ & $1,75-2$ \\
\hline Kömür & $3,50-4$ & $4,50-5$ & $5,50-5,75$ \\
\hline Maden kömürü & $16,50-18$ & $21-22$ & $22-25$ \\
\hline Elbiselik basma & 26 & 30 & 40 \\
\hline Şayak & 210 & 210 & 550 \\
\hline Serj & 390 & 420 & 670 \\
\hline Elbise dikimi & 1000 & 1300 & 1800 \\
\hline Ayakkabı & $400-500-800-900$ & 1000 & 1100 \\
\hline
\end{tabular}

Aynı şekilde Denizli Valisi Osman Nuri Tekeli de 13 Haziran 1942 tarihinde gönderdiği yazıda "eşya fiyatlarının harpten önceki yıllara göre yüzde yüzden yüzde beş yüze kadar yükselmesi karşısında geçimi harpten önceki gelirine bağll bulunan devlet memurlart ve müstahdemleri gibi mahut bir zümreyi kelimenin tam anlamıyla ezici" bir sıkıntı içinde bıraktığını belirterek memurlara asgari geçim sınırının sağlanmasını istemektedir ${ }^{22}$.

Memurların içinde bulunduğu durum karşısında valilerden sonra CHP Müstakil Grubu da bir rapor hazırlayarak memurlara yardım konusunda hükümete bazı tavsiyelerde bulunmuştur. Ekonominin sıkıntılı durumu Müstakil Grubun toplantısında görüşülmüş ve şu yönde kararlar alınmıştır: Memur ve ailelerine giyecek ve yiyecek yardımında bulunulması hükümete tavsiye edilmiştir. Ayrıca müzakereler sonucunda; küçük memur ve ailelerine ekmeğin parasız verilmesi, genel bütçeye, memıırlara yardım etmek üzere konulacak paranın bir kısmı ile vilayet ve kazalarda memur kantinlerinin kurulması ve memurların buradan alışveriş yapmalarının sağlanması gibi konularda çeşitli çözüm önerileri ileri sürülmüştür ${ }^{23}$.

Buğday üretimindeki düşüşün devam etmesi, tüketimin artması üzerine hükümet yeni tedbirler alma yoluna gitmiştir. Bu amaçla 21 Ocak 1942

${ }^{22}$ BMGME Katalog No:030.10.65.436.19.

${ }^{23}$ Müstakil Grubun raporunda 25 Ocak 1944 tarihi itibariyle devletin ücretli ve maaşlı memurlarının sayısı da belirtilmiştir. Buna göre Genel bütçe, katma, hususi bütçelerle belediyelerden maaş alanlarla emekli, dul ve yetimlerin sayısı toplam 316.576 kişidir. Aylık tutarı 10 liradan az olan ücretli ve maaşlı memur ve müstahdemlerin sayısı da 31.542 kişidir.BBKKE Katalog No:030.10.15.87.32. 
tarihinde 2/17199 numaralı bir kararname ile "hububat, bakliyat vesairenin un ezmelerinden pasta, çörek ve bunlara benzer" maddelerin yapılması ve satılması yasaklanmıştır ${ }^{24}$. Bakanlar Kurulu'nun çıkardığı bu kanun, 3/1691 numaralı ve 1 Kasım 1944 tarihli pasta, çörek, simit, bisküvi, börek, baklava ve benzeri hamur işi maddelerin yapılıp satılması hakkındaki yasağın kaldırılmasına dair karar ile hafifletilmiştir ${ }^{25}$.

Savaşın henüz ortalarında iken Türkiye'de 1942 başlarından itibaren ekmek tüketimi sınırlandırılmaya başlanmıştır. Bu amaçla hükümet 13 Ocak 1942 tarihinde 2/17141 numaralı kararnameyle ekmek ve ekmeklik hububat tüketimini sınırlamak amacıyla ekmeğin karneyle dağıtımına karar vermiştir.

\section{Ekmeğin Karneye Bağlanmast}

Hükümet, Milli Korunma Kanunun 21. maddesinde ${ }^{26}$ belirttiği gibi ekmek ve ekmeklik hububat tüketimini şu miktarlarda ve kart(karne) usulüyle sınırlandırmıştır. Buna göre:

7 yaşına kadar çocuklara (7 yaş hariç) günlük olarak ekmek miktarı 187,5 gram, 7 yaşından büyük olanlara 375 gram, ağır işçilere ${ }^{27}$ ise günlük 750 gram ekmek verilmesi kararlaştırılmıştır. Düzenleme yapılan köylerde ise büyük-küçük yaş sınırı gözetilmeksizin her nüfusa günde 300 gram ekmeklik hububat verilmesi kararlaştırılmıştır ${ }^{28}$. Bu arada, ekmeğin karne ile verilmesine dair 13 Ocak 1942 tarihli ve 2/17141 numaralı kararnameye 13 Nisan 1942 tarihli ve 2/1767 numaralı kararname bir ek yapılarak ekmek kartlarının günlük istihlak kuponları mukabilinde 375 gramlık ekmek için 125 gram hesabıyla glüten ekmeği verilebileceği belirtilmiştir ${ }^{29}$.

Bu kararnamelerden sonra 28 Ağustos 1942 tarihinde Ticaret Vekaleti'ne bağlı Toprak Mahsulleri Ofisi Umum Müdürlüğü tüm valiliklere gönderdiği genelge ile şehirlerde ekmek ihtiyacının nasıl karşılanacağını açıklamıştır. Genelgede, memleketin iaşesini ilgilendiren bu hususta mahalli idarecilere

${ }^{24}$ Düstur, 3. Tertip, C.23, Ankara 1962, s.131.

${ }^{25}$ Resmi Gazete, Sayı:5845.

${ }^{26}$ Milli Korunma Kanununun 21. maddesinde "Halksn ve milli müdafaanın kat'i ihtiyact olan zaruri maddelerin istihlak miktarın lüzum halinde Hükümet tahdit ve tayin eder" ifadesi bulunmaktadır. Ayrıntılı bilgi için Bkz: Düstur, 3. Tertip, C.21, Ankara 1940, s.436.

27 “Ağır işçi, sanayide, maden ve taş ocaklarında bina, yol, köprü ve emsali, nakil, tahmil ve tahliye, ormanlardan kat'iyat işlerinde mutat iş saatinin devam müddetince fasılasız surette büyük enerji sarfını icap ettirir ağır bedeni hizmetler gören veya şiddetli hararet, şiddetli ziya, şiddetli gürültü, teneffüs cihazın tazyik edecek bir buhar veya gaz veya sthhati tehlikeye düsürecek herhangi bir madde ile bozulmuș bir hava içinde çalıșmak zorunda bulunan kimseler" olarak tanımlanmışıır. Düstur, 3. Tertip, C.23, Ankara 1962, s.88.

${ }^{28}$ Düstur, 3. Tertip, C.23, Ankara 1962, s.88.

${ }^{29}$ Düstur, 3. Tertip, C.23, Ankara 1962, s.311. 15 Kasım 1942'de yeni bir uygulama başlatılarak ekmeğin iki ayrı fiyattan satılacağı belirtilmiştir. Halka 27 kuruștan, memura 14 ise kuruştan satılması kararlaştırılmıştır. Eser Tutel, "Tek Tip Ekmek Günleri”, Popüler Tarih, Sayı:40, Aralık 2003, s.69. 
geniş yetkiler verildiği belirtilerek kart(karne) usulünün sağlıklı bir şekilde yürütülımesi için belediye başkanları ve valilerin ahenkli bir şekilde bu işte çalışmaları istenmektedir ${ }^{30}$.

Karneyle ekmek dağıtımının ikinci bir düzenlemeye kadar şu illerde yapılması kararlaştırılmıștır: Ankara, Amasya, Aydın, Bilecik, Bitlis, Burdur, Bursa, Çanakkale, Cankırı, Diyarbakır, Edirne, Erzurum, Giresun, Gümüşhane, Hatay, İzmir, İçel, İstanbul, Isparta, Kars, Kastamonu, Kayseri, Kırklareli, Kocaeli, Malatya, Manisa, Mardin, Maraş, Muğla, Ordu, Rize, Samsun, Seyhan, Siirt, Sinop, Sivas, Tekirdağ, Tokat, Trabzon, Urfa, ve Zonguldak ${ }^{31}$.

Toprak Mahsulleri Ofisinin hazırlayacağı karneler, ilgili vilayetlere ulaștırıldığında bu kartların dağıtılması ve kontrolü gibi sorumluluklar vali ve belediye başkanlarına ait olması kararlaştırılmış, kart(karne) dağıtım işi yine aynı kurumlara verilmiştir. Belediyelerin dağıtacakları karneler için muhtarların her hane halkının nüfuslarını belirlemeleri gerekmekteydi ${ }^{32}$. Vatandașlara kart(Karne) dağıtılırken hüviyetlerini göstermeleri yeterli görülmüştür.

Kart usulüne tabi olmayan yerlerde de tüketimin başı boş bırakılmadığını, buralarda bulunan idare amirlerinin ve belediye başkanlarının tüketimi kontrol etmeleri ve kart ile verilen ekmek istihkaklarının sınırları içerisinde kalmaya dikkat etmeleri istenmektedir. Bu genelgenin sonunda Toprak Mahsulleri Ofisi antentli bir karne örneği ve ekmek tevzi bordrosu bulunmaktadır ${ }^{33}$.

Karne ile ekmek dağıtılması için çıkarılan kararnamenin tam açık olmaması nedeniyle halk ve karne sistemini uygulayan memurlar arasında yanlış yorumlara ve bazı sorunlar çıkmasına neden olmuştur. Bu durumun Ticaret Vekaleti'ne bildirilmesi üzerine Ticaret Vekili Dr. Behçet Uz, umumi müfettişliklere ve valiliklere gönderdiği bir genelgeyle bu türlü yanlıs anlașılmaların önüne geçilmesi istenmektedir. Buna göre ailenin iașesinden sorumlu olan aile reisinin bakmakla yükümlü olduğu aile üyelerine (eş, evlat, anne, büyük anne, kız kardeş ve torunlar dahil) de istihkak miktarlarına göre ekmek verilebileceği belirtilmiştir.

\footnotetext{
30 Ekmeğin karneyle dağıtılması, 14 Ocak 1942 tarihli Cumhuriyet Gazetesinde şöyle yankı bulmuştur: "bir kısım vatandaşların herhangi bir ihtiyat sevkiyle ve gündelik hislerle fazla ekmek satın alması yüzünden diğer bir kısım vatandaşların ekmeksiz kalmasını önleyeceği gibi hükümetimizin daha yüksek düşüncelerle karar altına aldığı șekilde üretimimizi muayyen bir hesaba göre tanzim edecek ve milli hayatımızın uzun bir zaman içinde devam edecek ihtiyaçlarım disiplin altına alacaktır" denilmekte ve halk karne ile ekmek alırken disiplin ve düzene davet edilmektedir. Cumhuriyet 14 Ocak 1942.

${ }^{31}$ BMGME Katalog No: 030.10.185.273.23.

${ }^{32}$ Tutel, a.g.m., s.67.

${ }^{33}$ BMGME Katalog No: 030.10.185.273.23
} 
Ayrıca Dr. Behçet Uz, daha önce belirlenen miktarlar dışında hiç kimseye günlük ekmek istihkakının üzerinde bir miktarda ekmek verilmesinin mümkün olmadığını ifade ederek sıkıntı çektikleri belli olan çok muhtaç kimselerin (emekli, yetim, dul) sıkı bir şekilde kontrol edilerek vekalete bildirilmesini istemiştir ${ }^{34}$.

\section{4. Şeker Tüketiminin Kısttlanması}

İkinci Dünya Savaşının etkileri ülke ekonomisinde sadece hububat temini konusunda olmamış, hububattan sonra şeker ve şeker ürünlerinde de kendini göstermiştir. Hükümet bu konuda şeker stoklarını daha verimli kullanabilmek amacıyla tüketimi kısıtlama yoluna gitmiştir. Bu amaçla ilk olarak 22 Ocak 1942 tarihinde çıkardığı 2/17197 sayılı kararname ile küp şeker fiyatına 62 , kristal şeker fiyatına da kiloda 45 kuruş zam yaparak tüketimi, fiyatları yükseltme yoluyla azaltmayı amaçlamıştır. Aynı kararnameyle şekerin perakende satışlarda azami satış miktarı bir kilo olarak belirlenmiş daha fazla şeker satın alınması yasaklanmıştır ${ }^{35}$.

$\mathrm{Bu}$ karar uyarınca şekeri ham madde olarak kullanan işletmelerin, ürettikleri ürünlerin dışında şeker satmaları ve başkasına devretmeleri de yasaklanmıştır. Ancak şekerin başka şekillerde kullanıldığına dair ve hükümete verilen beyannamelerin dışında şeker stoklayanların bulunduğu görülmüştür. Şeker bulundurma usullerinin hükümetçe belirlenmesine karşılık, izin verilen miktarın üzerinde şeker stoku yapanlarla ilgili olarak Milli Korunma Kanunu'nun 32. maddesi uygulanmış ve bazı tüccarlara karşı davalar açılmıştı ${ }^{36}$.

Şeker fiyatının artırılarak tüketime getirilen kısıtlamalardan sonra dar gelirlilere ve ihtiyaç sahiplerine hükümetin ucuz şeker dağıtması gündeme gelmiştir. Başbakanlığın 18 Mart 1942 tarihinde, "muhtaçlara ucuz şeker tevzii hakkında muhtıra" ile şekerin dağıtımı ile ilgili esaslar belirlenmiştir. Bu esaslara göre şeker dağıtımının yapılacağı iller ilk aşamada Ankara, İstanbul, İzmir, Zonguldak, Kayseri, Bursa, Adana, Malatya, İzmit, Eskişehir, Samsun ve Sivas olarak belirlenmiş, daha sonra uygun görülecek şehirlerdeki fakir çocuklara ucuz fiyatla şeker dağıtılması kararlaştırılmıştır.

1935 nüfus sayımına göre ülkede 0-5 yaş arasındaki çocukların sayısı 3.294.696 olarak belirlenmiş, hak sahiplerinden her birine yilda 6 kiloya yakın şeker dağıtılması hesaplanmış, bu durumda üç milyon kilo şeker dağıtılması planlanmıştır. Her ne kadar muhtıra olarak yazılsa da aslında tavsiye niteliği taşıyan metinde, şeker istihkakının her hafta çocuk başına 125 gram hesabıyla verilmesi tavsiye edilmektedir. Ayrıca dağıtımın kolay gerçekleşebilmesi için dağıtımın her mahallede bir bakkal seçilmek suretiyle

${ }^{34}$ BMGME Katalog No:030.10.185.274.8.

${ }^{35}$ Düstur, 3. Tertip, C.23, Ankara 1962, s.131.

${ }^{36}$ Bu konuda tüccarlara karşı açılan davalar için Bkz: Ayışı̆̆ı, a.g.m., s.239-240. 
yapılmasının doğru olacağı düşünülmüştür ${ }^{37}$. Bu muhtıradan sonra 25 Haziran 1942 tarihinde Sıhhat ve İçtimai Muavenet Vekaletinin hazırladığı geçimi müsait olmayan çocuklu ailelere, hastalara ve kimsesiz çocuklara parasız şeker dağıtımı hakkında talimatname yayınlanmıştır. Bu talimatname ile şeker dağıtımı hakkında daha açıklayıcı bilgilere sahibiz.

Geçim sıkıntısı çeken ailelerin çocukları ile hastalara ve kimsesiz çocuklara dağıtılacak şekerin kristal toz şeker olduğu, o bulunmazsa kesme şeker de verilebileceği belirtilmiştir. Talimatnamede fakirliğin ve geçim sıkıntısı çekenlerin tespitinde uygulanacak kriterler de belirtilmiştir. Buna göre aylık geliri 30 lira çocuklu aileler ve aylık geliri 40 liranın altında olan ailelere vesika(karne) verileceği de ifade edilmiștir. Parasız verilecek şeker miktarı çocuk başına ayda 500 gram olarak belirlenmiş ve bu miktarın her dört ayda bir toptan verileceği belirtilmiştir. Geçim sıkıntısı çeken ailelerin çocuklarına parasız şeker dağıtma yetkisi verilen vilayetlerin Sıhhat ve Içtimai Muavenet Vekaleti bütçesindeki tahsisattan kendilerine ayrılacak miktarda şeker satın alarak, tüketicilere dağıtmaları istenmiştir. Dağıtma işinde, CHP İçtimai Yardım Teşkilatı, Halkevleri ile Kızılay Cemiyeti, Çocuk Esirgeme Kurumu, Yardım Sevenler Cemiyeti ve Veremle Mücadele Cemiyeti gibi hükümetçe tanınmış hayır müesseseleri ile işbirliği yapılabileceği de belirtilmiştir.

Parasız şeker dağıtımının yapılacağı şehirler, şimdilik kaydı düşülerek Ankara, İstanbul, Konya, İzmir, Zonguldak, Kayseri, Bursa, Seyhan, Malatya, Kocaeli, Eskişehir, Samsun, Sivas, Aydın, Afyon, Bolu, Edirne, Elazı̆̆g, Erzurum, Hatay, İçel, Niğde, Amasya, Rize, Sinop, Trabzon ve Burdur olarak tespit edilmiştir. Bu illerin merkezlerinde ve belediye hudutları içerisinde aileleriyle birlikte ikamet edenlerin bu yardımdan istifade edeceği belirtilmiştir ${ }^{38}$.

Şeker dağıtımının nasıl yapılacağını gösteren bu talimatnameden önce, 23 Ocak 1942'de CHP Genel Sekreteri ve Erzurum Milletvekili A. Fikri Tuzer tarafından Başvekil Dr. Refik Saydam'a yazılan yazıda, 23 Ocak 1942 tarihinden itibaren şeker tüketimin sınırlandırılması amacıyla, fiyatının yükseltildiğini belirterek, partinin himayesinde İstanbul'da kız ve erkek, Denizli'de ve Malatya'da birer erkek yurdu olmak üzere toplam dört tane öğrenci yurdu bulunduğunu belirterek, bu yurtlara, "kadro mevcutları üzerinden ucuz seker" verilmesini rica edilmektedir. Aynı süreçte Sıhhat ve İçtimai Muavenet Vekili Dr. Hüsnü Alataş imzasıyla 27 Şubat 1942 tarihinde Başvekalete gönderilen yazıda, "Hastane, Darülaceze ve talebe yurtları" gibi muayyen bir bütçeyle idare edilen müesseselerin veya genel bütçe ile belediyelerden destek gören kuruluşların alacakları şeker fiyatında indirim yapılmasına gerek olmadığı belirtilmiştir ${ }^{39}$. Benzer bir istek de

\footnotetext{
${ }^{37}$ BMGME Katalog No: 030.10.179.235.17.

${ }^{38}$ BMGME Katalog No: 030.10.181.250.6.

${ }^{39}$ BMGME Katalog No: 030.10.179.235.17.
} 
Çankırı Valiliğinden gelmiştir. Çankırı Valisi Ali Rıza Noyan, 6 Mart 1942 tarihinde Başvekalete yazdığı yazıda Çankırı'da bulunan 50 yataklı, "memleket hastanesiyle çocuk esirgeme kurumuna bağlı süt damlasında $a^{40, "}$ günlük dört kilo süt sarf olunduğunu belirterek, bütçelerinin darlığı yüzünden ihtiyaçları oranında şeker tedarik edilemediğini ifade etmiş, kendilerine zam yapılmadan yevmiye dört kilo şeker verilmesini talep etmiştir ${ }^{41}$.

Şeker tüketimine getirilen sınırlamadan sonra Bakanlar Kurulu'nun 1 Temmuz 1943 tarihinde kabul ettiği 2/20243 sayılı kararnameye göre "değişmez ve dar gelirlilere ucuz fiyatla tevdi edilmekte bulunan şeker miktarının, I Temmuz 1943 tarihinden, değişmez gelirliler için nüfus başına ayda 600 gramdan bir kiloya ve dar gelirliler için de 300 gramdan 500 grama" çıkarıldığı açıklanmıştır.

Hükümet, dağıtımını, karneye bağladığı ekmek ve şekerin dağıtımını kolaylaştırmak amacıyla Ticaret Vekaletince belirlenecek yerlerde 5 Mayıs 1942 tarihinde Halk Dağıtma Birlikleri kurarak ihtiyaç maddelerini doğrudan tüketiciye ulaştırmayı hedeflemiştir ${ }^{42}$. Halk Dağıtma Birliklerinin, ticaret odasına kayıtlı olan ve birliğin dağıtımını yapacağı maddelerin satışını yapan bir ticarethanesi bulunan vatandaşlardan oluşturulması kararlaştırılmıştır. Halk Dağıtma Birlikleri talimatnamesine göre, her 250 hanelik veya 1000 nüfusluk halk kitlesinin bir dağıtma birliği teşkil etmesi kararlaştırılmıştır. Köylerin ise kendi başlarına bir dağıtma birliği oluşturması planlanmıştır. Halk Dağıtma Birlikleri'ne, hükümetçe dağıtılması kart(karne) usulüne bağlanmış olan ekmek ve şekerin dağıtımını organize etmek, doğrudan doğruya müstehlike(tüketiciye) dağıtılması hükümetçe uygun görülen maddelerin dağıtımını temin etmek, dağıtımın hangi gün ve nerede yapılacağı konusunda birlik üyelerini bilgilendirmek görevi verilmiştir. Ayrıca köyde bulunan her türlü üretim maddelerini tespit etme görevi de Halk Dağıtma Birlikleri'ne verilmiştir.

Okul, çocuk yuvası, hastane ve hapishane gibi toplu tüketim yapan yatılı kurumların başlı başına birer dağıtma birliği olacağı belirtilmiştir.

Ayrıca, Hükümet, Halk Dağıtma Birlikleri adıyla bir dağıtım teşkilatı kurarak ihtiyaç maddelerini vatandaşlara daha iyi bir şekilde ulaştırmayı amaçlarken diğer taraftan da mevcut imkanları daha iyi kullanmak adına ekmeğin gramajını sürekli değiştirmek yoluna gitmiştir. ${ }^{43}$ Hükümet,

\footnotetext{
${ }^{40}$ Süt Damlası, Çocuk Esirgeme Kurumunda bulunan çocuklara süt sağlamak amacıyla oluşturulan bir kurum.

${ }^{41}$ BMGME Katalog No: 030.10.179.235.18.

${ }^{42}$ BBKKE. Katalog No:030.18.01.02.98.36.13.

${ }^{43}$ Cemil Koçak, 13 Nisan 1942 tarihinde günlük ekmek istihkakının 7 yaşından büyükler için 175 grama, Mayıs ayında ise 150 gram olduğunu ifade etmektedir. Cemil Koçak. "Türkiye'de Karneli Yıllar", Tarih ve Toplum, Sayı:25, Ocak 1986, s.26-27.
} 
çıkardığı 2/19065 sayılı ve 19 Kasım 1942 tarihli kararnamede ise memur ve müstahdemlerin ekmek istihkaklarının 600 gram olarak kararlaştırılmışıı ${ }^{44}$.

İkinci Dünya Savaşı'nın ülkemize neden olduğu sıkıntıları önleyebilmek ve mevcut imkanları daha iyi ve daha verimli kullanabilmek amaciyla ülke genelinde, ekmek ve şeker dağıtımında uygulanılan kısıtlamalar(karne uygulaması) 11 Aralık 1945 tarihinden itibaren tamamen kaldırılarak, normal düzene dönülmüştür ${ }^{45}$.

Savaşın bitiminden iki yıl sonra 12 Aralık 1947 tarihinde Bakanlar Kurulu, Milli Korunma Kanunu'nun 21. maddesine dayanarak daha önce defalarca değiștirdiği, imal edilecek ekmek tipindeki sınırlamada bir adım geri atarak bazı unlu mamullerin yapılmasına izin vermiștir. Bakanlar Kurulu'nun 3/6682 numaralı kararnamesine göre buğday unundan ekmek, francala, pide ve sandvich'in evlerde ve hastanelerde yapılmasına izin verilecek, ancak dışarıya satılması ve bedelsiz olarak dahi verilmesi hala yasak olacaktr ${ }^{46}$. Son olarak 17 Ağustos 1948 tarihinde Bakanlar Kurulunun verdiği 3/7904 numaralı karar uyarınca un ve ekmek imalatını sınırlayan tüm kararnamelerin kaldırıldığı açıklanacaktır ${ }^{47}$.

\section{Memurlara Giyim Yardımı}

Savaş yıllarında yiyecek maddelerinde kendini gösteren darlık nedeniyle sıkıntı çeken vatandaşlar, sürekli yükseliş trendinde olan enflasyon nedeniyle ihtiyaçlarını temin edemiyorlardı. Ekmek, şeker gibi yiyecek maddelerini her vatandaşa temin etmeye çalışan hükümet, giyim eşyası konusunda ise devlet memurlarına farklı davranmış̦tır. Hükümet halkla sürekli temas halinde olan memur ve müstahdemlerin, devletin temsilcileri olduğunu düşünmekteydi. Her türlü zor şartlar altında bile memurların giyim kuşamlarının daha iyi olması, devletin kutsandığı Tek Partili dönemde çok önemliydi. Memurlar sarsılmaz devlet baba imajının temsilcileriydiler ve her şeye rağmen iyi görünmek zorundaydılar. Bu düşünce doğrultusunda Hükümet, ücretleri yüksek enflasyon karşısında yetersiz kalan memurlara giyim eşyas $1^{48}$ yardımı yapmak için 13 Kasım 1942 tarihinde, "Devletçe Parasız Verilecek Giyim Eşyası" hakkında 4306 sayılı kanunu çıkarmıştır. Bu kanun uyarınca, genel, katma ve özel bütçeli kurumlardan maaşa alanlarla, belediye çalışanlarına giyim eşyası yardımı yapılmasına karar verilmiştir.

${ }^{44}$ BBKKE Katalog No:030.18.01.02.100.98.16

${ }^{45}$ Cumhuriyet, 11 Aralık 1945.

${ }^{46}$ Düstur, 3. Tertip, C.29, Ankara 1948, s. 45.

${ }^{47}$ Düstur, 3. Tertip, C.29, Ankara 1948, s.1345.

${ }^{48} \mathrm{O}$ dönemde yiyecek mallarındaki üretim sıkıntısının yanı sıra, dokuma üretimimiz de yetersiz durumdaydı. Kayseri, Nazilli, Malatya, Ereğli pamuklu dokuma fabrikalarına rağmen, ülkedeki toplam pamuk üretimi 70 milyon metreden ibaretti. Yani nüfus başına yılda 4 metre düşmekteydi. Aydemir, a.g.e., s.217. 
$\mathrm{Bu}$ kanun uyarınca memur ve müstahdemlere, subay ve askeri memurlara, gedikli erbaşlara, okul pansiyonlarında çalıştırılan eğitmenlere, posta-telgraf ve telefon memurlarına, köy eğitmenlerine ve öğretmenlerine, radyoda çalıșan yevmiyeli sanatkarlara bir defaya mahsus olmak üzere parasız giyim eşyası verilmesi kararlaştırılmıştır. Buna göre maaşı 75 liraya kadar memurlara ve eşlerine birer elbiselik kumaş, kendilerine birer çift ayakkabı, maaşının toplamı 140 liraya kadar olanların kendilerine ve eşlerine birer elbiselik kumaş, aylık ve tahsisatlarının tutarı 140 liradan yukarı olan memurların sadece kendilerine elbiselik kumaş verilmesi kararlaştırılmıştır. Memurlara verilecek ücretsiz giyim eşyası toplam üç metre kumaş olarak belirlenmiştir.

Karı ve kocanın memur olması durumunda, eşlerinin yalnız kendi vazifelerinden dolayı müstahak oldukları giyim eşyasını almaları şartı getirilmiştir. Bu durumlarda, "kocalarından dolayı başkaca bir şey verilmez" hükmü de ayrıca belirtilmiştir ${ }^{49}$. Bir aileye iki yardım yapılmaması için yardımların kocaya verilmesi hükmü ilerleyen sürede tepki çekmeye başlamış ve bu konuda bazı istekler Başbakanlığa ulaşmıştır. 20 Ocak 1946 tarihinde Ankara Kız Lisesi Türkçe Öğretmeni Mükerrem Kamil Su, Başbakanlığa yazdığı mektupta "geçim yükünü paylaşmak zorunda kalan kadının" memurlara yapılan ayni yardımda "bir ayrılığa tabi tutulmaması", nı rica etmektedir ${ }^{50}$. Ancak bu tür istekler kabul edilmemiştir.

Devlet memurlarına parasız giyim yardımı yapılmasına ilişkin kanun çıkmadan önce, Vakıflar Umum Müdürlüğü tarafından Başvekalete yazılan yazıda, ülkenin içinde bulunduğu şartlar nedeniyle memurlara bedelsiz elbise ve ayakkabı verileceğini duyduklarını belirterek, "umum müdürlüğ̈̈̈n memurin ve müstahdeminin" bu yardımdan "deriğ buyrulmamasını" rica edilmektedir. Yazının Başvekalette işlem gördüğü, üzerine yazılan el yazısından anlaşılmaktadır. Yazıda, "Buna ait esaslar kararlaştırılmış değildir, şimdilik” ifadesi bulunmaktadır (3 Eylül 1942) ${ }^{51}$. Memurlara yapılan yardımın kapsamı zamanla genişletilerek daha fazla memurun yararlanması hedeflenmiştir. Bu amaçla 19 Temmuz 1943 tarihinde çıkartılan "Cami ve mescit hademelerine Parasız Elbiselik Kumaş Verilmesi” hakkındaki kanunla Vakıflar Genel Müdürlüğü bütçesinden maaş alan, "camii ve mescit hademelerine yerli fabrikalar ürünlerinden bir defaya mahsus olmak üzere parasız üçer metre elbiselik kumaş” verilmesi kararlaştırılmıştı1 ${ }^{52}$.

\footnotetext{
${ }^{49}$ Düstur 3. Tertip, C.24, Ankara 1964, s.17-18.

${ }^{50}$ Başbakanlık Devlet Arşivleri Genel Müdürlüğü, Başbakanlık Cumhuriyet Arşivi, Başbakanlık Özel Kalem Müdürlüğü Evrakı. Bundan sonra BÖKME şeklinde kısaltılacaktır. Katalog No:030.01.87.547.14.

${ }^{51}$ BMGME Katalog No:030.10.189.294.19.

${ }^{52}$ Düstur, 3. Tertip, C.24, Ankara 1964, s.637.
} 
Ekmeğin ve şekerin daha sonra da diğer ihtiyaç maddelerinin karneyle dağıtılması beraberinde bazı sıkıntıları da beraberinde getirmiştir. Karne uygulaması konusunda yanlış uygulamaların dışında, bazı kötü niyetli kişilerin bu sıkıntılı dönemde ortaya çıkarak kendilerine menfaat temin ettikleri görülmektedir ${ }^{53}$. Bu konuda basına yansıyan haberlerin dışında ${ }^{54}$ taşradan da merkeze bazı ihbarlar ulaşmışıฺı ${ }^{55}$.

İkinci dünya Savaşı yıllarının olumsuz ekonomik koşullarından zarar gören memurlar için başlatılan giyim yardımı günümüzde de uygulanmaktadır.

\section{Fevkalade Durum Yardimlart}

Hükümet, ekmek ve şekerin karneyle dağıtımını gerçekleştirdikten sonra, piyasada sürekli artan ve engellenemeyen fiyatlar karşısında devlet memurlarını ekonomik olarak güçlendirme düşüncesi gündeme gelmiştir. İthalat imkanlarının yetersiz olması nedeniyle hayat son derece pahalılaşmış, en zorunlu ihtiyaç maddeleri bile ancak karaborsadan yüksek fiyatla temin edilebilir olmuştur.

Bu durum karşısında Şükrü Saraçoğlu hükümeti önce sadece ayni yardım yaptığı memur ve müstahdemlere artık nakdi yardım yapma kararı da almıştır. Bu amaçla, Maliye Vekaleti Bütçe ve Mali Kontrol Umum Müdürlüğü'nün hazırladığı, "Memur ve Müstahdemlere Verilecek Fevkalade Zam Hakkında Kanun" 28 Ocak 1942 tarihinde 4178 say1 ile kabul edilmiştir. Buna göre fevkalade hallerin devamı müddetince, aylık tutarı 100 liraya kadar maaşı olanlar için, vergi ve tekaüt tevkifatı çıtıktan sonra ita miktarının \%25'i, 101 liradan 170 liraya kadar maaşı olanlar için \%20'si ve maaşı 170 liradan yukarı olanlar için de $\% 15$ oranında zam yapıldığı açıklanmıştır.

Ayrıca memurlara çocuk zammı da düşünülmüş, bu amaçla tüm devlet memurlarından 4 veya daha fazla çocuğu bulunanlara dördüncü çocuktan itibaren çocuk başına ayda iki buçuk lira verilmesi kararlaştırılmıștır. 4178 sayılı kanunun 9. maddesi subay ve askeri memurlarla ilgilidir. Kış

${ }^{53}$ Şevket Süreyya Aydemir, "Haydarpaşa istasyonunda tesadüfen hamalın strtından düşerek parçalanan bir sandıktan dökülen binlerce ağır iş̧̧i ekmek karnelerini bastıran ve dağıtan dolandırıcı- Bu sahte vesikalar tam taklit sayılmaz. Çünkü şu köşedeki çizgilerden birisi aslına tam benzemiyor- gerekçesiyle ve hiç tutuklanmadan serbest birakılıyordu" şeklinde o dönemde yapılan uygulamalarla yolsuzlukların üzerine bile gidilemediğini anlatmaktadır. Aydemir, a.g.e., s.216.

54 "Istanbul'da ortaya çıkan karne yolsuzluğunun çok büyük boyutlarda olduğu ve her karne dağıtımında beș bin karnenin çalındığı anlaşılımıştır" Cumhuriyet 22 Kasım 1943.

${ }^{55}$ Ankara Kızılcahamam Cumhuriyet Savcılığı Katibi Emin Yılmaz, 9 Ekim 1945 tarihinde Başvekalete gönderdiği mektubunda istihkaklarının kendilerine parayla satıldığını şikayet etmektedir. Bu şikayete verilen cevaba bakıldığında ise şikayetin adeta geçiştirildiği görülmektedir. BBKKE Katalog No: 030.10.65.437.4. 
şartlarının ülkenin diğer bölgelerine göre oldukça sert geçtiği Doğu Anadolu bölgesinde görev yapan memurlara yakacak yardımı yapılarak, zaten çok yetersiz olan maaşlarının büyük bir bölümünün ısınma giderine gitmesini önlemek amaçlanmıştır. Buna göre ücretleri genel bütçeden ödenen memur, askeri memur, subay, aile sahibi gediklilerden " 1500 ve daha yukarı rakımlı yerlerde daimi memuriyette bulunanlara her ytlın Ilkteşrin ayından başlamak ve Mart nihayetine" kadar devam etmek üzere; 1-6. derecede olan memurlara her ay otuz lira, 7-15. derecede olan memurlara da her ay on beș lira yakacak zammı verilmesi kararlaştırılmıştır. Rakımı 1500 ve daha yukarı olan vilayetler; Ağrı, Bitlis, Erzurum, Gümüşhane, Hakkari, Kars, Muş, Van olarak belirlenmiştir. Ayrıca bu illere bağlı, kaza ve nahiyelerden 1500 metre ve üzerinde olanlar da belirtilmiştir ${ }^{56}$.

Memurlara yapılan maaș zammından sonra fevkalade durumun devam ettiği gerekçesiyle 21 Haziran 1944 tarihinde 4599 sayılı, "Fevkalade Hallerin Devamı Müddetince Memur ve Müstahdemlere Yapılacak Yardım Hakkında" kanun çıkartılmıştır. Bu kanunla yardım yapılacak memurların kapsamı genişletilmiştir. Buna göre genel, katma ve özel bütçeli kurumlarla, belediye bütçelerinden 3599 sayılı kanuna giren memur ve müstahdemlere, okul pansiyonlarında çalıştırılanlara, "odacı, kolcu, bekçi, evrak müvezzi, gemi mürettebatı, ücretli ve aidatl tahsildar, daktilo ve steno gibi çeşitli müstahdemlere" köy öğretmenlerine, köy eğitmenlerine, köy ebelerine, seyyar sıhhat memurlarına, yardımcı muallimlere, camii ve mescit hademeleriyle, vaiz ve dersiâmlara, açık maaşı alanlara, birinci ve ikinci derecede askeri malullere, evlenmeğe mezun gedikli(kıdemli) başçavuşlara, başgediklilere, deniz ve hava kadrolarında bulunan gedikli subaylara, evlenmeğe mezun jandarma gedikli erbaşlarla, temditli erata fevkalade hallerin devamı müddetince ayni yardım yapılması kararlaştırılmıştır. Bu yardımdan aile başına yarı nispette, mütekaitlerle ve dul-yetimler de istifade edebileceklerdir. Yapılacak yardımın her ay düzenli bir şekilde yapılması, aylık tutarının 15 liradan az olmaması belirlenmiş, ayrıca memur olan karı ve kocadan sadece kocaya yardım yapılması kararlaştırılmıştır ${ }^{57}$.

4599 sayılı kanundan sonra memur ve müstahdemlere yapılan fevkalade haller yardımı daha düzenli bir hal almış, ayrıca dağıtılması kararlaştırılan ürünlerin fiyatları da belirtilmiştir. Buna göre 31 Ağustos 1944 tarihinde Bakanlar Kurulu'nun çıkardığı 3/1441 sayılı kararnameye göre Temmuz, A ğustos, Eylül 1944 aylarına ait yardım tutarının 15'er lira olarak tespit edilmesine karar verilmiştir. Ayrıca İçişleri, Maliye, İktisat, Ulaştırma ve Ticaret vekaletlerince belirtilen aylarda dağıtılması kararlaştırılan şekerin

\footnotetext{
${ }^{56}$ Türkiye Cumhuriyeti Maliye Vekaleti, Bütçe ve Mali Kontrol Umum Müdürlüğü, Memur ve Müstahdemlere Verilecek Fevkalade Zam Hakkindaki 4178 Savilt Kanun ile İahnamesi, Damga Matbaası, Ankara 1942, s.1-27.

${ }^{57}$ Düstur, 3. Tertip, C.25, Ankara 1970. s.357-359.
} 
kilosunun kristal şeker için 120, küp şeker 140 kuruş, has unun kilosunun da 42 kuruş olarak tespit edilmesine karar verilmiştir ${ }^{58}$.

Bu kararnameden yaklaşık iki ay sonra 3/1576 sayılı yeni bir kararname daha çıkarılarak Ekim, Kasım, Aralık 1944 ve Ocak 1945 aylarına ait yardım tutarları 15 lira olarak tespit edilmiş, dağıtımı kararlaştırılan 10 kilo sabunun her kalıbının 250 gram itibariyle memur başına 40 kalıp üzerinden verilmesi ve kilosunun 65 kuruş olarak tayinine karar verilmiştir. Ayrıca Kasım, Aralık 1944 ve Ocak 1945 aylarından itibaren cârî perakende satış fiyatlarına göre ilgililer lehine \%25 indirimli bir şekilde giyim ve ev eşyası verilmesi kararlaştııılmış ve bu konuda bir talimatname hazırlanmıştır.

Memurlara, Yerli Mallar Pazarları Mağazası bulunan yerlerde aynî yardım bedelleri için kupon verilmesi kararlaştırılmıştır. "I kinci teşrin 1944, Birinci kanun 1944 ve Ikinci kanun 1945" tarihlerine ait ayni yardım paraları aydan aya ilgili kurumlarca 15'er lira olarak ödeneceği belirtilmiştir. Yardım bedellerini nakden almak istemeyip de aynen almak isteyenler için de onların istediği şekilde hareket edileceği ifade edilmiştir. Kupon sahibi olan memurlar 15'er liralık kuponlarla Yerli Mallar Pazarları Mağazası'ndan cârî satış fiyatlarıyla kupon tutarının \%25 fazlasına istedikleri malları alabileceklerdi. Ancak her ne kadar istedikleri malları alabilecekleri söylense de bazı mallara kısıtlama getirilmiştir. Satışı daha önce sınırlandırılan basma, kaput bezi ile pazenden herhangi birisinden kupon başına en fazla beş metreden fazla mal verilemeyeceği belirtilmiştir. Memurların, kuponların üzerinde de alışveriş yapabileceği, ancak arada oluşan fiyat farkını ödemeleri gerektiği ayrıca belirtilmiştir.

Zat maaşı alan emekli dul ve yetimlere de memurlara verildiği gibi kupon verilmesi kararlaştırılmıştır. Zat maaşları için bir aylık istihkaka karşılık beş metre ve üç aylığ belirtilmiştir. Kupon sahiplerinin perakende cârî satış fiyatları ile 9.37 liraya tekabül eden mal verilmesi ancak kupon karşıllığında ince yünlü erkek elbiseliği kumaş alamayacakları kararlaştırılmıștır ${ }^{59}$.

Bu kararnameden sonra 28 Ocak 1945 tarihinde çıkarılan bir kararname ile olağanüstü hallerin devamı süresince memur ve müstahdemlere yapılacak yardım hakkındaki 4599 sayılı kanunun 2. ve 12. maddelerine ek yapılmıştır. Bu kararnamede her aya ait yardımın 15'er lira olması kararlaştırılmış, ayrıca ilk aşamada sadece memur ve müstahdemlere dağıtılan şekerin kilosu kristal için 120 kuruş, küp şeker için 140 olarak belirlenmiştir ${ }^{60}$.

Bu tarihten sonra 29 Aralık 1945 tarihinden 2 Ocak 1947 tarihine kadar her altı ayda bir çıkartılan ve hemen hemen aynı içeriğe sahip olan kararnamelerle memurlara ve emeklilere her ay $15^{\prime}$ er lira yardım

\footnotetext{
${ }^{58}$ BBKKE: Katalog No: 030.18.01 .02.106.62.5

${ }^{59}$ BBKKE Katalog No:030.18.01.02.106.68.20

${ }^{60}$ BBKKE Katalog No:030.18.01 .02.107.95.3.
} 
yapılmasına karar verilmiştir. Ayrıca ilerleyen tarihlerde çıkartılan kararnamelerle yardımdan faydalanacak memurların kapsamı da genişletilmiştir ${ }^{61}$.

Fevkalade hallerin devamı müddetince memur ve müstahdemlerle dar gelirlilere yapılan yardımlara 4 Şubat 1946 tarihinden itibaren zeytinyağ yardımı da eklenmiştir. Dağıtılacak zeytinyağı miktarı değişmez gelirliler için nüfus başına 2 litre, dar gelirliler için nüfus başına 1 litre verilmesi kararlaştırılmıştır. Memur ve müstahdemlere dağıtılacak zeytinyağının fiyatı Ankara'da 210 kuruş, İstanbul'da 206 kuruș, İzmir'de ise 201 kuruş olarak belirlenmiştir. Değişmez gelirliler ile memur ve müstahdemlere yapılacak dağıtımlarda Ocak, Şubat dönemine ait ekmek kartlarından, üç büyük ilde bulunan dar gelirliler ise, kendilerine ait tevziat kartından yararlanmaları istenmiştir $^{62}$.

\section{CHP'nin Kendi Memurlarına Yardımı}

Hükümetin maddi sıkıntı içerisinde bulunan devlet memurlarına ve dar gelirlilere yaptığı ayni yardımlar Cumhuriyet Halk Partisi'nin de kendi çalışanlarına böyle bir yardım yapmasını gündeme getirmiştir. CHP Genel Sekreteri adına İzmir Mebusu R. Köken, tarafından 24 A ğustos 1944 tarihinde yayınlanan genelgede, hükümetin fevkalade hallerin devamı müddetince devlet memurlarına ve müstahdemlerine aynî yardım yapılması için 4599 sayılı kanunun çıkartıldığını belirterek, CHP teşkilatında aylık ve ücretle çalışan memur ve müstahdemlere de ayni yardım yapılması tavsiye edilmiştir. Ancak yapılması tavsiye edilen yardımın mahalli bütçelerin imkan ve müsaadesine bağlanmıştır. Dolayısıyla merkezin böyle yardıma imkanı olmadığı açıklanmıştır. Yardımın mahalli idareler tarafından hangi esaslar içerisinde yapılacağı Genel Sekreterlik tarafından belirlenmiştir. Belirlenen bu kriterler daha önce hükümetin çıkardığı yardım kararnamelerinde bulunan hükümlerin benzeridir ${ }^{63}$.

\section{SONUÇ}

İkinci Dünya Savaşı'nın ilk günlerinden itibaren yükselmeye başlayan fiyatlar karşısında değişmez ve dar gelirle geçinmeye çalışan milyonlarca insanı büyük bir sıkıntı içerisinde bırakmıştır. Yetersiz sanayi üretimi, yüksek tüketim gideri ve dış ticaret ilişkilerinin bozulması nedeniyle yeterli miktarda ithalat da yapılamamıştır. Ülkede temel ihtiyaç maddelerinin, karaborsaya düşerek fiyatlarının çok yükselmesi karşısında geçim sıkıntısı çekmeye başlayan sabit gelirlilere yani memurlara ve az sayıda dar gelirli vatandaşlara, hükümet diğer vatandaşlardan farklı olarak şeker, zeytinyağ ve giyim eşyası yardımı yapmıştır. Ayrıca savaşın ilerleyen yıllarıyla beraber

\footnotetext{
${ }^{61}$ BBKKE Katalog No:030.18.01.02.109.77.3.

${ }^{62}$ BBKKE Katalog No: 030.10.28.163.4.

${ }^{63}$ Başbakanlık Arşivleri Genel Müdürlüğü, Cumhuriyet Arşivi Daire Başkanlığı, Cumhuriyet Halk Partisi Evrakı, Katalog No: 490.01 15.25.2.
} 
hükümet yardım görenleri ve yardım maddelerinin kapsamını genişleterek memurların sıkıntılarını hafifletme yoluna gitmiştir. Bu süreçte şehirlerde oturan ve devletten bu şekilde yardım gören sabit ve dar gelirli vatandaşların sayısı 1.600.000 kişiye ulaştığı görülmektedir ${ }^{64}$.

Hükümetin tüm halka değil de sadece belli bir kesime yardım yapması toplumu ikiye bölmüştür. Bir yanda yokluk ve sıkıntı içersinde yaşam mücadelesi veren halk, diğer yandan da savaş yıllarında ihtiyaçlarının karşılanabilmesi için devlete yapılan mecburi mahsul teslimi ve vergiler yüzünden kendi hayat standardını düşürmek durumunda bırakılan köylüler bulunmaktayd ${ }^{65}$. Sıkıntı içerisinde bulunan vatandaşlar yerine sadece memurlara yardımın yapılması, halk ile memurların arasını açmıș, halk artık memura kötü gözle bakmaya başlamıştır. Buna karşılık devlet, halk ile memurlarını birbirinden ayırdığının farkında olmayıp kendi memurlarını koruyabilmenin mücadelesine devam etmekteydi. Bu yardımlar çerçevesinde Sümerbank'ın memurlara ucuz fiyatla verdiği kumaş ve ayakkabılar ucuz fiyatlarıyla halkın kıskançlığına sebep olmakta ve halkın memurlara olan tepkisini artırmaktaydı ${ }^{66}$.

Aslında CHP'nin asker ve sivil bürokrat kesime yaptığı yardımlar, onun sınıfsal temelinden kaynaklanıyordu. Milli Mücadelenin başlarından itibaren asker-sivil yönetici kesim ve yerel eşraf şeklinde örgütlenen bürokrasiyi, hükümetlerin koruması son derece olağan bir durumdu. Cumhuriyetin kurumsallaşmasıyla beraber, genişleyen ve güçlenen bürokrasi, cumhuriyet devrimlerine bağlılı̆̆ının ödülünü, İkinci Dünya Savaşı sırasında çekilen sıkıntılar karşısında kendisine yapılan ayni ve nakdi yardımlarla görmüştür.

Hükümetin bu politikası, Milli Mücadeleden beri devam eden CHPBürokrasi dayanışması sonucunda geriye itilen geniş halk kitlelerini devletin partisi olan CHP'den uzaklaştıran önemli bir etken olmuştur. Yıllardır devam eden tek parti yönetimi altında beklentilerine cevap alamadan yaşayan vatandaşlar, Demokrat Partinin ortaya çıkmasıyla kendini hor gören CHP'den uzaklaşmaya başlamıştır. Bir memur ve eşraf teşkilatlanması halinde görülen CHP, gayri memnun vatandaşların DP'ye yönelmesi karşısında şaşırmış ve DP'liler "Hasolar ve Memolar" diye adlandırılmışıิır ${ }^{6^{3}}$.

${ }^{64} 1940$ yılında Türkiye'nin toplam nüfusu 17.820.950'dir. Bu nüfusun sadece \%31.9'u şehirlerde yaşamaktadır. Ayrıntılı bilgi için bkz., İstatistik Genel Müdürlügüu, Küçük Istatistik Yıllı̆̆ı 1947-1950, Ankara 1951, s.22.

${ }^{65}$ Karpat, a.g.e., s.120.

${ }^{\alpha s}$ Toker, a.g.e., s.23.

${ }^{67}$ Cemil Koçak, Türkive'de Milli Şef Dönemi (1938-1945) C.2, İstanbul 1996, s.544; Samet Ağaoğlu, Demokrat Partinin Doğuş ve Yükseliş Sebepleri-Bir Soru, 1972, s.9;Çetin Yetkin. Türk Halk Hareketleri ve Devrimler, İstanbul 1980, s.496-497. 


\section{KAYNAKLAR}

\section{Arşivler}

Başbakanlık Cumhuriyet Arşivi

\section{Gazeteler}

Cumhuriyet

Resmi Gazete

\section{Kitaplar}

Ağaoğlu, Samet, Demokrat Partinin Doğuşve Yükseliş Sebepleri-Bir Soru, 1972.

Aydemir, Şevket Süreyya, Íkinci Adam, C.2, 2000.

Ayışı̆̆ı, Metin, “İkinci Dünya Savaşı Başlarında İstanbul'da İhtikar Meselesi”, Altınci Askeri Tarih Semineri Bildirileri 1, 20-22 Ekim 1997, İstanbul 1999.

Düstur, 3. Tertip,

Goloğlu, Mahmut, Milli Şef Dönemi, Ankara 1972.

İstatistik Genel Müdürlügüü, Küçük İstatistik Yıllı̆̆ı 1947-1950, Ankara 1951.

Karaosmanoğlu, Yakup Kadri, Politikada 45 Yıl, İletişim Yayınları, İstanbul 1999.

Karpat, Kemal, Türk Demokrasi Tarihi- Sosyal, Ekonomik, Kültürel Temeller, İstanbul 1996.

Koçak, Cemil, Türkiye'de Milli Şef Dönemi(1938-1945) C.2, İstanbul 1996.

, "Türkiye'de Karneli Yıllar", Tarih ve Toplum, Sayı:25, Ocak 1986.

Pamuk, Şevket, “İkinci Dünya Savaşı Yıllarında İaşe Sorunu ve Köylülük”, Tarih ve Toplum, Sayı:35, Kasım 1986.

Tezel, Yahya Sezai, Cumhuriyet Döneminin Iktisadi Tarihi, Ankara 1986.

Timur, Taner, Türk Devrimi ve Sonrası, Ankara 1997.

Türkiye Cumhuriyeti Maliye Vekaleti, Bütçe ve Mali Kontrol Umum Müdürlüğü, Memur ve Müstahdemlere Verilecek Fevkalade Zam Hakkındaki 4178 Sayll Kanun ile İzahnamesi, Damga Matbaası, Ankara 1942.

Toker, Metin, Tek Partiden Çok Partiye 1944-1950, Bilgi Yayınevi, Ankara 1998.

Tutel, Eser, “Tek Tip Ekmek Günleri”, Popüler Tarih, Sayı:40, Aralık 2003.

Yerasimos, Stefanos, Azgelişmişlik Sürecinde Türkiye, (Çeviren Babür Kuzucu), C.3, İstanbul 1992.

Yetkin, Çetin, Türk Halk Hareketleri ve Devrimler, İstanbul 1980. 